\title{
Addressing Pedagogical Training Needs of Teaching Staff: Lessons from Makerere University Short Professional Development Programs 2006 - 2010
}

\author{
Betty Akullu Ezati ${ }^{1, *}$, Charles Opolot-Okurut ${ }^{1}$, Proscovia Namubiru Ssentamu ${ }^{2}$ \\ ${ }^{1}$ Makerere University \\ ${ }^{2}$ Uganda Management Institute \\ *Corresponding author: bezati@cees.mak.ac.ug, itaze@yahoo.com
}

Received November 13, 2014; Revised December 02, 2014; Accepted December 08, 2014

\begin{abstract}
In Uganda, university teachers are recruited on the strength of their class of degree rather than pedagogical content knowledge and skill. Given the frequent changes in technology with resultant paradigm shifts from teacher to learner-centered education and competence-based approaches, increasing demand of accountability from society, and demand for quality, among others, university teaching can no longer be left to subject expertise alone. Effective teaching and quality graduates requires university teachers to possess a combination of content and pedagogical knowledge. Using data collected through an interview guide and end-of-workshop evaluation questionnaire for a four-year training period (2006 - 2010), this article focused on the lessons learnt from a series of pedagogical training workshops offered by Makerere University management to her teaching staff. Findings show that the main training needs among the teaching staff include assessment and grading of students, managing large classes, and using ICT in teaching and learning. Overall, the staff appreciated the workshop methodology, the coteaching approach and the sharing of experiences. However, there were concerns about the timing of the trainings and inability to implement what is learned due to institutional constraints. The study underpins the importance of undertaking needs assessment before designing any staff training program. Rather than claim that addressing individual training needs will improve quality, staff pedagogical training should be combined with institutional changes so that institutional constraints that hinder utilization of knowledge and skills acquired during training are concurrently addressed. In addition, training approaches should transcend the deficit model of continuous professional development commonly used to the use of a variety of models including the cascaded model. Through the cascade model the capacity of academic staff could be built, these would continue to learn from each other, thereby developing a critical mass at faculty or academic unit level.
\end{abstract}

Keywords: pedagogical content knowledge, pedagogical training needs, university teaching, teachers, continuous professional development models

Cite This Article: Betty Akullu Ezati, Charles Opolot-Okurut, and Proscovia Namubiru Ssentamu, "Addressing Pedagogical Training Needs of Teaching Staff: Lessons from Makerere University Short Professional Development Programs 2006 - 2010.” American Journal of Educational Research, vol. 2, no. 12 (2014): 1190-1198. doi: 10.12691/education-2-12-9.

\section{Introduction}

Changes in higher education (HE) including funding, competition amongst institutions, increased use of technology and a shift to learner-centered education are combining to modify the roles of both universities and staff $[3,4,50]$. The changing environment is forcing higher education institutions (HEI) to rethink their practices in teaching, research and knowledge management. As [8] noted, students learn at different rates and are on different levels even at same ages, implying that lecturers cannot treat all students the same. Unfortunately, lecturers are regrettably ignorant about the choice and use of pedagogical methods which are suitable for an education that relies more and more on higher level cognition and interpersonal abilities [7]. This is because in many countries, in applying for a university teaching position, an applicant needs not to present any evidence of teaching ability [7]. A PhD or its equivalent is the key criterion usually required to show scholarly competence, but nothing is required to demonstrate pedagogical competence, a competence in the very skills one is expected to use on the job [6]. While universities recruit first class graduates as lecturers, concerns have arisen over their capacity to pass on knowledge to students. Without high-quality initial training, teachers largely teach the way they were taught. It is difficult for them to adapt and adopt learner-centered pedagogy [50]. The editorial in the Uganda New Vision Daily Newspaper [37] asserts that 'being a genius does not necessarily make one a good tutor'. This indicates that intellectual competence and pedagogical competence are 
two different qualities. One cannot be an outstanding lecturer without thorough knowledge of subject matter; but to possess that knowledge does not guarantee the ability to communicate it to a student [6]. Therefore lecturers should be taught teaching methodology, lecture room control, marking etiquette, and research supervision and communication skills [37]. Similarly, [2] explains that if undergraduate education is to be enhanced, faculty members, academic and students affairs administrators must devise ways to deliver undergraduate education that is as comprehensive and integrated as the ways students actually learn.

Given this scenario, provision of continuous professional development for university teaching staff is no longer debatable. Teaching in higher education requires skills that can no longer be left to experience but best developed through formal training to meet new demands [20]. This is because professors cannot master effective teaching and learning on their own initiative at a reasonable speed [20]. Critical information must be imparted to employees to ensure that they meet their responsibilities [1]. [38] contends that teachers should be able to learn how to learn, adopt new methods of teaching, facilitated by the new technology. Yet, not all teachers, especially in higher education, are adequately prepared to meet the diverse needs of today's students.

\section{Conceptual Review}

Pedagogy is a scientific discipline with its own philosophical and scientific orientations borne between the $18^{\text {th }}$ and $20^{\text {th }}$ centuries. Because of its double stance, namely the theoretical and practical components, the discipline has continued to spark-off various interpretations and controversies [36]. For instance, it has been defined in different ways, including the study of being a teacher or the process of teaching, strategies of instruction or style of instruction. Other scholars have used pedagogy in relation to the art and science of teaching children, or the theory and practice of education [22]. Pedagogy can also refer to the relationship between the teacher and the student. Conceptually, it is due to the relationship of pedagogy to children that some scholars prefer the use of andragogy (the art and science of helping adults learn) when referring to teaching in higher education. However, [13] used critical pedagogy to refer to the method of teaching adults. If pedagogy is viewed as focusing on transmitting content in a teacher-controlled environment and andragogy on facilitating the acquisition of and critical thinking about content and application in real life [21] then both are relevant to higher education. Therefore pedagogical content knowledge is according to [44] the specialized didactic knowledge of the teacher, which illuminates the connection between subject matter and classroom knowhow. Pedagogical content knowledge brings together these two critical elements of teaching — content and pedagogy — to describe the understanding and skills teachers and teacher educators need to transform the conceptual, factual, with appropriate examples, metaphors, and applications for a particular group of students [50]. This paper adopts the use of pedagogy in line with [13] view.

Meanwhile, continuous professional development (CPD), a structured approach to learning helps ensure competence in practice. CPD helps in the construction and adaptation of mutually shared networks of theory and practice [46]. There are several CPD models. [20] identifies three main categories of CPD models including, transmission, transformation and transition. According to Kennedy, transmission is composed of three sub-models; namely 'training', 'award-bearing' and 'deficit' models. The 'training model' according to [20] is when teachers are provided with opportunity to update their skills in order to be able to demonstrate their competence, while the 'award-bearing model' emphasises the completion of award-bearing programs of study - usually, but not exclusively, validated by universities. The 'deficit model' is usually designed to address a perceived deficit in teacher performance.

The second main category is transformation, which includes 'action research' in which teachers themselves are learners and researchers, with a view to improving the quality of action within it. The transformative model combines practice and experience sharing. The 'quality of action' can be perceived as the teachers' understanding and interpretation of the situation, as well as the practice within the situation. This model considers teachers as being empowered to use the pedagogical spaces in more situated ways.

The third model is transitional, which combines 'coaching/mentoring', 'community of practice' and 'standard models'. In 'coaching/mentoring' emphasis is on a one-to-one relationship, usually between two teachers, (one novice and a senior), which is designed to support CPD. 'Community of practice' involves more than two teachers. Learning involves mutual engagement, understanding and tuning teachers' enterprise and developing repertoire, styles and discourses [20]. Learning within a 'community of practice' happens as a result of that community and its interactions, and not merely as a result of planned learning episodes such as programmed courses of study.

The cascade model (not categorised among the three) involves individual teachers attending 'training events' and then cascading or disseminating the information to colleagues. Commonly employed in situations where resources are limited, the cascade model can be used to strengthen the three main models.

According to [20], the CPD model adopted is dependent on the purpose. If the aim is preparing teachers to implement reforms then transmission models are preferred. For supporting teachers to contribute to and shape educational policies, one should adopt the transformative model. Transitional models can be used to support the first two models. These models provided a lens through which the Makerere University pedagogical program was evaluated.

\section{Contextual Perspective of Pedagogy for Teachers at Makerere University}

Since its inception, Makerere University has experienced several changes in the curricular, staffing and student enrollment, among others. Prior to the 1970s, the university had a small population of about 2000 students [48]. But, with the liberalization policy of the 1990s, in less than a decade, the student population rose from less 
than 10,000 to about 40,000 students [27]. At present, it is estimated that the University admits $75 \%$ of the total university student population in the country. Yet, lecture room space that was previously used to teach 50 students in the 1960s and 1970s is the same in some cases for about 1000 students.

In the 1970s, government expenditure on Makerere University (the only university then) was between 25\% and $30 \%$ of the total budget allocated to the education sector. This figure has since 1997 dropped to around 15\% as a result of the initiation of the Universal Primary Education (UPE) program and in 2007 Universal Post Primary Education and Training (UPPET) in 2006. This shift meant that the tertiary education sub-sector has suffered from less funding since then. Between 1987/8 and 1995/6, government only approved an average of $45.6 \%$ of the funds requested by Makerere University, but not all the approved money was remitted [18].

The increasing numbers of students amidst decreasing resources and government funding, inadequate facilities, $[19,26]$ coupled with high attrition among staff have raised public panic about the capacity of Makerere University to deliver quality education. Challenges of designing relevant and demand-driven curricula have also been pointed out [26] as affecting the quality of education offered. There are concerns that Makerere University is producing graduates that do not match the demand of society [29]. The argument is that the discrepancies between competencies acquired in education and those required in real life have become more pronounced. It has been noted that teaching staff at Makerere University lacked staff induction program and had limited orientation to pedagogical and e-learning skills [24].

With the intent to become 'a center of academic excellence, providing world class teaching, research and service to sustainable development for Uganda, Makerere University in its Strategic Plan 2008/09 -2018/19, committed itself to;

1. Shift from teacher-centered instruction to learnercentered pedagogy in order to produce graduates with problem solving skills and reflective ability,

2. Place more premium on research so as to focus on knowledge production as a research driven university, and

3. Replace the outreach paradigm with its patronage connotation and instead embrace knowledge transfer partnership and networking in order to take cognizance of the knowledge that resides in the community, private, governmental and nongovernmental organizations [26].

This paper focuses on Makerere University’s efforts to address the first strategic objective above.

Scholars assert there is no single ingredient that has greater impact on student achievement than the quality of the teacher [14]. This is because the success of any innovation depends on the development of teaching staff to meet the demands of new ways of working and teaching [47]. The professional development component of the Quality Assurance Policy avers that teachers need to be supported to gain skills of maintaining and enhancing academic standards, pastoral care and social life of students [28]. Believing that promoting better teaching practices through continuous professional development is part of the drive for quality and excellence, Makerere
University targeted the teaching staff in its attempt to implement the Strategic Plan and since 2006, the University has been re-tooling teaching staff through periodic provision of short pedagogical training programs. The training programs were intended to change the existing paradigm of teaching staff towards teaching and learning.

\section{Statement of the Problem}

Although effective teaching and learning is at the heart of Makerere University's Quality Assurance Policy of 2007 , teaching remains relatively poor [24,25]. Yet since 2006, the University has been offering pedagogical training programs as an intervention to improve the quality of teaching. While such a reform aimed at improving the quality of HE, complaints about the quality of the graduates persist. The researchers pose several questions related to the perception of the teaching staff towards the pedagogical training program; the choice of model(s) used, the content, and the timing of the training. This study therefore analyzed lecturers' perception of the professional development course; specifically their perception of the CPD, key knowledge gaps of the teaching staff and whether the training met their expectations.

\section{Purpose of the Study}

This study aimed at assessing the extent to which the pedagogical training program meets the training needs of the teaching staff.

\section{Objectives}

This study was guided by the following objectives:

1. To find out the extent to which the Makerere University pedagogy training programs addressed participants' training needs as teachers in higher education.

2. To find out participants' perception of the pedagogy training programs offered at Makerere University.

\section{Methodology}

This study followed a descriptive survey research design based on mixed methods. This was because responses to the research questions required methods that utilized both qualitative and quantitative methodological frameworks [49]. Elsewhere, mixed methods are observed to be technical [5] since they are designed to fit a specific set of cases of contexts as was the case in this study. Among the advantages of using mixed methods is their ability to answer exploratory questions, and simultaneously verify and generate theory in the same study. Furthermore, mixed methods allow researchers to thoroughly understand the educational activities in context and to provide recommendations that can be generalized.

The target population for the study included all Makerere University teaching staff who participated in the four-year pedagogical training workshops from the 
faculties of Agriculture, Law, Veterinary Medicine and the East African School of Library and Information Sciences. These faculties were selected by the Deputy Vice Chancellor's Office in charge of Academic Affairs (DVCAA). The Office of the DVCAA identified and sent information regarding staff pedagogical training to the deans of the selected faculties. The deans in turn informed members of staff in their respective units of the training opportunity. Participation was therefore voluntary. A total of 101 staff participated in this study (71 males and 30 females) as shown in Table 1.

Data collection

Two instruments were used for data collection: an interview guide and end-of-training open-ended questionnaire. The data collection process followed the ensuing pattern of activities. First, at the commencement of each workshop, participants were given two VIPP cards of different colors and asked to reflect on their current pedagogical practices and write their strengths and areas in which they needed improvement. Observation shows that this activity was not done with ease because many participants noted that it was much more comfortable assessing others than themselves. Although selfevaluation is an essential element for improvement, this study showed that the teaching staff find difficulty engaging in it, an indication that reflective practice is not yet wholly embraced by the teaching staff. Similar conclusions are drawn from a study by [35] in which it is observed that in a training workshop scenario participants are less critical of themselves as individual learners, and that being non-self critical and non-reflective about one's own learning could be considered from a wider Ugandan cultural perspective. However, in the current study, with encouragement from the facilitators, the participants were able to note down their strengths and training needs, which were read out and displayed on the wall to enable participants and facilitators further reflect and analyze them.

Secondly at the end of each of the three days of the four training workshops, post-training evaluation questionnaires with open-ended questions were completed by each of the participants to establish whether their training needs had been met.

The validity and reliability of the tools were ensured by using a wide sample across the four-year span and all the four training workshops conducted. In addition, during the preparation of the training and evaluation materials, the facilitators ensured face validity by focusing the questions for the interview and those for the evaluation form through peer review checks. The same data collection tools were used in all the four training workshops.

Data analysis

Data was analyzed using descriptive statistics and interpretive analysis. Interpretive analysis aimed at a view that knowledge is more dynamic than is implied in the cause-effect laws. As a means of analysis, it seeks to generate information from experiences [32,43] of the participants. Interpretive analysis was therefore aimed at presenting interpretation of reality as lived experience, i.e. as the participants saw and lived it in the University learning environment.

The data was collated per question and organized in terms of the collective responses to the questions and not per faculty. The data was then organized and categorized guided by the research questions, to enable the identification of themes and emerging patterns. Data coding was done simultaneously with the application of descriptive statistics to compute frequencies that facilitated the analysis and interpretation of the findings. Further analysis involved searching for thematic connections within and across the transcripts [31,43]. In addition, comparisons and contrasts in terms of gender, university teaching experience and faculty were drawn.

\section{Results and Discussion}

Results are in response to the study questions; (1) To what extent have the training programs addressed participants' training needs as teachers in higher education; (2) What are the participants' perceptions of the pedagogical training programs offered by Makerere University?

Demographic information of the participating teaching staff

Table 1 provides the demographic profile of participating teaching staff in the sample. The table shows the number of years of teaching experience and the gender of the participants by faculty.

Table 1. Experience of staff in teaching and gender by faculty

\begin{tabular}{|c|c|c|c|c|c|}
\hline $\begin{array}{c}\text { Experience in } \\
\text { Teaching } \\
\text { (years) }\end{array}$ & Agriculture & EASLIS1 & Law & $\begin{array}{c}\text { Veterinary } \\
\text { Medicine }\end{array}$ & Total \\
\cline { 2 - 6 } 0 - 5 years & 2 & 2 & 3 & 5 & 12 \\
\hline 6 - 10 years & 6 & 5 & 7 & 8 & 26 \\
\hline $\mathbf{1 1 - 1 5}$ years & 13 & 12 & 10 & 6 & 41 \\
\hline $\mathbf{1 6}$ - 20 years & 6 & 3 & 4 & 2 & 15 \\
\hline > 20 years & 1 & 1 & 3 & 2 & 7 \\
\hline Gender Male & 16 & 17 & 19 & 19 & 71 \\
\hline Female & 12 & 6 & 8 & 4 & 30 \\
\hline Total & 28 & 23 & 27 & 23 & 101 \\
\hline Source: Primary & & & &
\end{tabular}

Source: Primary data

Table 1 shows that teaching experience of the participating academics varied from $<5$ years $(11.9 \%)$, the majority of whom were from the Faculty of Veterinary Medicine to over 20 years (7\%) of experience in teaching mainly from the Faculty of Law. Majority of the participants had a teaching experience of between 11 and 15 years. There were few staff who had a teaching experience of over 20 years, indicating that majority of the teaching staff were where either in their early- or midcareer. Consequently, such training was beneficial for them. Table 1 also reveals that out of the 101 academics who participated in the study, $29.7 \%$ were females and $70.3 \%$ were males. This implies that there were about twice as many male than female academics.

To what extent have the training programs addressed participants' training needs as teachers in higher education?

a) Participants training needs

In order to ascertain the training needs of the study participants, participants were asked to reflect on their strengths and areas of improvement. On areas of improvement, the participants reported various key areas and topics as requiring attention in preparing teachers to teach in higher education. The main areas identified

1 East African School of Library Information Sciences 
included assessment, ICT and curriculum design. Table 2 illustrates the key areas noted by the respondents.

Table 2. Training needs of study participants

\begin{tabular}{|l|c|}
\hline Areas and Topics of Concern & $\begin{array}{c}\text { Percentage } \\
\mathbf{\% ~ N ~} \mathbf{~ 1 0 1}\end{array}$ \\
\hline 1. Assessing, marking and grading of students' work & 78 \\
\hline 2. Using ICT in teaching and e-learning & 72 \\
\hline $\begin{array}{l}\text { 3. Aligning course goals, teaching strategies, objectives } \\
\text { and assessment }\end{array}$ & 65 \\
\hline 4. Using learner-centred approaches in large classes & 62 \\
\hline 5. Balancing course content with time available & 60 \\
\hline 6. Planning course lessons & 58 \\
\hline 7. Communication & 54 \\
\hline 8. Better teaching techniques & 52 \\
\hline 9. Supporting students of various backgrounds & 52 \\
\hline 10. Tolerating stubborn students and uncooperative staff & 50 \\
\hline
\end{tabular}

Source: Primary data

(Areas of $<50 \%$ not reported)

It is clear from Table 2 that key training needs among the teaching staff who participated in the workshops focus around pedagogical content knowledge. This is because the staff from the four participating faculties in the training workshops did not have an educational background on pedagogy and andragogy training. Only few staff from Agriculture had some training in education extension.

Findings show that the highest training need was in the area of assessment and evaluation of students' work, cited by $78 \%$ of the teaching staff. More specifically, the participants wanted more attention to be given to the following assessment issues:

\section{Setting standard examinations}

2. Using good assessment skills and continuous feedback

3. Difficulties with marking students' scripts

4. Learn good assessment techniques

5. Acquire course evaluation techniques (Workshop 1 participants)

Source: Primary data

Another key area mentioned that needed attention is the use of ICT and e-learning cited by $72 \%$ of the respondents.
In its ICT Policy of 2010, Makerere University committed itself to train staff in ICT on a continuous basis in order to build their expertise and experience so as to enhance its teaching and learning approaches [23]. Such training would also ensure that staff are competent enough to use ICT resources and to keep abreast of the dynamic and ever changing nature of ICT amidst massification in higher education. Further, as stated in the Makerere University ICT Master Plan (2010 - 2014, page 16), “it is University Policy to train staff on a continuous basis in basic ICT skills and other skills relevant to their jobs and require that all new staff to be recruited possesses the relevant ICT skills for the jobs applied for. In this way, Makerere University hopes to contribute to better quality graduates and to provide greater access to university education, by developing capacity for increased enrolment through nonconventional approaches in teaching and learning such as Distance Education and Virtual University. It is possible that this policy had triggered more demand for ICT.

The lowest recorded concern was handling stubborn and uncooperative staff as part of management, cited by about $50 \%$ of the teaching staff. The areas that were named by less than $50 \%$ of the respondents were not reported in this paper.

The following responses further captured the concerns of some of the sampled teaching staff:

I expect this course to help me with ways of balancing course content with time duration (Workshop 1 participant).

I hope to get knowledge in effective planning of course lessons and gauging depth and width of content to give students of different levels especially at bachelors, masters and doctoral levels (Workshop 2 participant).

I wish this training could equip me with ways of engaging students actively in class. In all, I need better teaching skills (Workshop 4 participant).

I am not very patient with slow learners. I wish I could get help on this (Workshop 3 participant)

With regard to the strengths of the study participants, findings showed that slightly more than half of them were good at content knowledge. This is illustrated in Table 3.

Table 3. Percentages of participants reporting various self-confessed strengths

\begin{tabular}{|c|c|c|c|c|}
\hline No & Category & $\begin{array}{l}\text { Indicators of Strengths of } \\
\text { Participants as teachers in a HEI }\end{array}$ & Number of Occurrences & $\begin{array}{c}\text { Percentage (\%) } \\
\mathrm{N}=101\end{array}$ \\
\hline \multirow{4}{*}{1.} & \multirow{4}{*}{ Content Knowledge } & - Knowledge of subject content & 60 & 59.4 \\
\hline & & - Adequately qualified & 41 & 40.6 \\
\hline & & - Eager to learn & 11 & 10.9 \\
\hline & & - ICT skills & 10 & 9.9 \\
\hline \multirow{7}{*}{2.} & \multirow{7}{*}{ Personal Personality } & - Love for teaching profession & 41 & 40.6 \\
\hline & & - Commitment to work & 31 & 30.7 \\
\hline & & $\begin{array}{l}\text { Humorous and lively teaching } \\
\text { Motivator of students }\end{array}$ & $\begin{array}{l}26 \\
12 \\
\end{array}$ & $\begin{array}{l}25.7 \\
11.9\end{array}$ \\
\hline & & - Punctuality & 9 & 8.9 \\
\hline & & - Available to guide students & 8 & 7.9 \\
\hline & & - Good interpersonal skills & 5 & 5.1 \\
\hline & & - Able to work under pressure & 5 & 5.1 \\
\hline \multirow{4}{*}{3.} & \multirow{4}{*}{ Pedagogical Skills } & - Good communicator & 25 & 24.8 \\
\hline & & - Regular planning and preparation & 14 & 13.9 \\
\hline & & - Loud and clear voice projection & 10 & 9.9 \\
\hline & & $\begin{array}{l}\text { - Lecture room management skills } \\
\text { - knowledge of students \& their needs }\end{array}$ & $\begin{array}{l}6 \\
6\end{array}$ & $\begin{array}{l}5.9 \\
6.9\end{array}$ \\
\hline 4. & Experience & $\begin{array}{l}\text { Setting good tests and examinations } \\
\text {-Experience in teaching }\end{array}$ & $\begin{array}{c}5 \\
22\end{array}$ & $\begin{array}{c}5.1 \\
21.8\end{array}$ \\
\hline
\end{tabular}

Source: Primary data 
An analysis of Table 3 shows the emergence of four major categories of academic staff strengths, i.e. content knowledge, personal personality, pedagogical skills and teaching experience. However, some of the indicators overlap among the major categories, especially under personal knowledge and pedagogical skills. As evidence of adequate content knowledge, several of the respondents noted that they were either 'knowledgeable of the subject matter' or 'had good understanding of content and subject matter.' The high response on knowledge content as a strength is because during recruitment, knowledge of content is a key criteria. Indeed, in Makerere University a good degree has been the major criterion. It is the faith in academic qualification that made Makerere University to raise recruitment criteria for lecturers from Master's degree to $\mathrm{PhD}$. Yet many scholars have argued that knowledge of content alone is not sufficient. For instance, [44] posits that both knowledge of content and pedagogical content knowledge constitute the professional base of teaching. It is also important to note that only 59\% of the study participants reported strength in content knowledge, an indication that some of the teaching staff may require support in both content and pedagogical knowledge. This calls for a systematically organised CDP that continuously updates teaching staff knowledge and skills of the teaching staff. As one of the respondents from Workshop 3 explained, "Such courses need to be conducted periodically to enlighten us on new methods and even new content". Similarly another participant from Workshop 2 reported, "Teaching and learning being dynamic, requires constant and periodic update”.

Ranked second in Table 3 was personal character. Although majority of the study participants had no prior training in the pedagogy of higher education, they were committed to teaching. This study confirms that teacher personality, though an often neglected area in teacher research plays a significant role in shaping the nature and character of teachers. According to [35], the knowledge, skills and personalities of the facilitators are key ingredients in enhancing learning. Elsewhere, research has show that teachers' behaviour is more crucial for student learning than teachers' cognition, although the two aspects influence each other [16]. Perhaps teacher personality is one of the most distinguishing attributes between various teachers.

Third in the categories was strength in pedagogical skill. Although majority of the study participants acknowledged having had no prior exposure to pedagogical training, findings in Table 3 illustrate that some participants had some pedagogical skills including good communication skills (24.8\%), and regular planning and preparation (13.9\%) ranking highest in this category. It is possible that such skill could have been developed through individual experience and modeling other teachers. However, it can also be observed that other than regular planning and preparation, lecture room management, and setting good tests and examinations, the other pedagogical skills indicators highlighted under this category are generic in nature. Further, there is a weak link between subject content and art and science of teaching. For instance, being a good communicator does not necessarily translate into being a good university teacher, yet vital indicators under this category, i.e. regular planning and preparation, lecture room management, and setting good tests and examinations, were ranked lower than the possession of good communication skills.

From the foregone discussion, several study participants had varying strengths in the mastery of subject matter and were committed to their teaching. However, majority of them lacked pedagogical skills and teaching experience, hence suggesting a weak link between content and pedagogical knowledge. A strong link between content and pedagogical knowledge supports teachers to understand and interpret the curriculum, know the learners and their characteristics, the educational context, the educational purpose and values as essential [44]. Further, according to [36], a teacher with pedagogical content knowledge is able to make informed decisions when selecting instructional content and how such content should be taught to result into learning.

b) Extent to which the training met the needs

A comparison of the areas staff identified as needing improvement (Table 2) and the training content preselected by the facilitators showed that on the whole, the pre-selected course content was aligned to the needs of the teaching staff. The pre-selected content included 8 main areas namely,

i) Theories about learning and pedagogical knowledge

ii) Preparation: Course planning and curriculum writing

iii) Learning goals and outcomes

iv) Course alignment

v) Instructional strategies

vi) Assessment and evaluation: testing and examinations

vii) Student support

viii) Being a course leader

Source: Primary data

As illustrated above, participants' training needs related to assessment, course planning, and student support were covered. However, information and communication technology which was the second highest identified area requiring improvement was not provided for in the training program. In addition, failure to include strategies of managing large classes in the pedagogical training programs left some participants dissatisfied. However, as [1] asserts, among the characteristics of formal training include the fact that some content is relevant to some and not so relevant to others. Hence, this training left some staff unsatisfied. Nevertheless, during the training, reference was made to the knowledge gaps identified by the participants. In this way some of the training needs that were not in the program were brought in during discussion.

This means that identification of training needs is key in providing just-in-time training, where what is taught is immediately applicable in the current work situation. In such training, participants' work is a central feature of the subject matter.

\section{What are the participants' perceptions of the pedagogical training programs offered by Makerere University}

Generally the teaching staff had a positive attitude towards the training program. They particularly appreciated the participatory and co-teaching approaches used during the training. The detailed findings are presented and discussed below.

\section{Participatory training approach}

In order to enhance experiential learning, the facilitators ensured that the participants were informed of the 
workshop objectives and created a learning environment where all the participants felt comfortable to share their experience. For instance, during introduction participants shared things about them that nobody in the group knew. In this way teaching staff of different levels freely interacted. As [1] explains, all training should (1) provide participants with the objectives, (2) create a conducive learning environment, (3) make use of blended learning approaches, (4) adopt a systematic presentation, (5) use planned and blended approach to the delivery of learning, (6) identify learning and development needs, and (7) evaluate the effectiveness of the training process. Facilitators adopted participatory approaches in which participants shared amongst themselves and with the facilitators.

The training methods used enabled the participants to become active agents of their own learning. According to [39] experiential learning takes place when people learn from their experience by reflecting on it so that it can be understood and applied. Learning is therefore a personal construction of meaning through experience. Constructivists such as [41] believe that experiential learning is enhanced through facilitation that creates an environment in which people can be stimulated to think and act in ways that help them make good use of their experience. In addition, productive learning takes place in non-competitive socially constructed environments where learners learn from each other. As posited by [35], the degree of support obtained from other learners or participants, gives learning a social dimension, which is significant in adult learning. Therefore, the role of facilitators or mentors in fostering participatory strategies to learning cannot be underestimated.

\section{Reflective approach}

Since all the participants had some teaching experience at the university level, facilitators made use of this to encourage reflection on their current teaching practices during the workshops. In this way, the training workshops availed the participants with opportunity to reflect on such practices with the aim of further improving to meet the required higher education pedagogical competency and expertise. At the same time, reflection is vital when practitioners are faced with new problems or difficulties for which they have not been specifically trained [42]. Reflective practice requires the practitioner to contemplate on his/her current practice with a view to making it better. [15] puts reflective practice/action research at the heart of teaching scholarship.

According to [45] effective professional development will deepen a participant's understanding, transform beliefs and assumptions, and create a stream of continuous actions that change habits and affect practice. Hence, there is need for institutions to strive for an environment where teachers have the time to reflect and retool, have ready access to local and global ideas and resources that are logically and socially indexed, have the skills to research, evaluate, collaborate, remix, and implement new tools and techniques (contemporary literacy), are part of an ongoing professional conversation where the expressed purpose is to provoke change (adapt).

By encouraging reflection, facilitators ensured close alignment between the course content and activities the participants are daily engaged in during teaching. As [11] explain, pedagogical content knowledge should be organised in ways that closely align to teachers' professional practice, including opportunity to enact certain innovative instructional strategies and materials to reflect individually and collectively on their experience.

\section{Use of team teaching}

In addition, the facilitators adopted the team- or coteaching approach, which was greatly appreciated by the participants. Until about 5 years ago, co-teaching was foreign to Makerere University. Many times teaching staff managed courses alone. The advantages of co-teaching are several including increasing communication between teachers and students and improving retention and achievement [9]. During the workshops, co-teaching provided opportunity for the participants to have firsthand experience on 'how co-teaching is done'. [12] argues that it is not merely the type of professional knowledge being acquired that is important, but the context through which it is acquired and subsequently used that actually helps us to understand the nature of that knowledge.

On the negative side, participants raised concerns on the duration of the training and timing of the workshops.

\section{Duration of the workshops}

Most of the participants noted that four days was very long, and therefore recommended reduction in the number of workshop days. Although each workshop was scheduled to take five days, the days were reduced to 3.5 days. The first half day of the workshops was devoted to introducing participants to the program, reflecting on strengths and areas of improvement, brain storming about participants' expectations, and harmonizing expectations. The remaining three days were devoted to sharing of experiences on pedagogical content knowledge and skills.

\section{Timing of the workshops}

In addition, some of the participants noted that the workshops were offered during wrong periods of the university calendar year. The workshops were all held during university recess. As [17] advices training should be scheduled to ensure availability so that participants' attention is focused on learning. However, it is difficult to resolve scheduling of training given that university teaching staff are busy throughout the year teaching, marking and grading, conducting and supervising research, writing and presenting papers in conferences. [8] explains that many teachers within the higher education environment do not have the time for new initiatives because they are fully committed to trying to do everything else that they have been allocated. Further, [33] also notes un-expanded staff establishments amidst increased student enrolments levels, which increase staff to student ratios and staff teaching load. [17] also advices that weekends should be avoided because that is when workers take time off. He suggests organizing training during normal working hours. This would send a message to the participants that learning is as important as their job. Makerere University pedagogical trainings were conducted towards weekends. Indeed during the trainings, some participants abstained on Sunday, while others failed to attend Friday and Saturday evening sessions. Incentives should be put in place to encourage participants' attendance in programs that are voluntary but strongly encouraged by the institution. For instance, ongoing professional development could be made a condition of employment [50].

Concerns about effects of institutional constraints on implementation of knowledge and skills obtained 
Participants were also concerned about their ability to transfer the knowledge and skills acquired during the training. Many of them pointed out that the changes such as the learner-centred approach advocated for during the workshops would be difficult to implement due to inadequate resources, large classes, tight teaching timetables, and short timelines provided to mark and submit results. This confirms the views that the deficit model of CPD which attempts to remedy perceived weaknesses among individual teachers may not lead to changes in practice. As [34] explains a number of the new proposed strategies need only be modified through managerial intervention. [40] observe that the root causes of poor teacher performance are related not only to individual teachers, but also to organisational and management practices. Using a deficit model implies that collective responsibility is not considered, i.e. that the system itself is not considered as a possible reason for the perceived failure of a teacher to demonstrate the desired competence [20]. [34] adds that teachers are constrained by the lecture room resources, social as well as material of their circumstances. Therefore, whilst creativity is possible, it is within circumscribed limits because the material and social features of a teacher's environment exert selection pressures as to which varieties of action will continue to be sustainable in the lecture rooms [20]. This is possibly why [30] advices that institutions should encourage risk taking and discourage the psychologically easier path of not changing. This can be done with institutional structures that support each individual. Support that does not depend on the individual's continual success and embraces failures are the result of considered risk taking. There was likelihood that some of the participants in the current study could still slip back to their former ways of doing things. It was very difficult to change participants' attitudes towards a number of issues regarding curriculum design, teaching, learning and assessment.

\section{Conclusions and Study Implications}

On the whole, the pedagogical training program in Makerere University adopts the transmission model, specifically the 'training' and deficit models. However, [1] contends that this 'deficiency' model of training, i.e. only putting things right that have gone wrong, is limited. Rather, learning should be more concerned with identifying and satisfying developmental needs [at organizational level]. Satisfying these needs means '...fitting people to take on extra responsibilities, increasing all-round competence, equipping people to deal with new work demands, multi-skilling, and preparing people to take on higher levels of responsibility in future' [1]. On the other hand, the 'training model' has been criticised for its lack of connection to the context in which teachers work [20]. The choice of the workshop methodology to use is as important as the content to be delivered. In pedagogical training workshops, this means adopting the methodology being promoted during presentation.

This study suggests adoption of the cascade model in trainings of this nature, to enable academic staff from the same faculty to train their colleagues. The aim of fostering faculty or unit-based communities of practice is that there will be a multiplier effect since through this model more staff are likely to be trained at their places of work. In this way, the staff would be able to improve on both content and pedagogical knowledge. Learning through communities of practice is integral to life, and, if learning is viewed in this way, professional lives require creating and sustaining 'communities of practice' in which teacher educators can 'live and learn' as professionals. Such communities, then, become valuable tools for learning, growth and development [10]. Professional learning communities provide peer support. However, this is dependent on the ability of the university management to foster such learning communities at faculty and basic unit levels.

\section{Acknowledgements}

This study was carried out with the permission of the former Deputy Vice Chancellor (Academic Affairs) of Makerere University Prof. Lillian T. Ekirikubinza who was in charge of organizing the workshops. We would like to thank her office for giving us the opportunity to facilitate in the series of training workshops for the teaching staff since 2006. We thank the Carnegie Foundation for funding the training workshops. Furthermore, we appreciate all teaching staff that attended and participated in the training workshops. We also appreciate our colleagues with whom we facilitated the workshops; Dr Mary Goretti Nakabugo (2006 - 2008) and Dr Ronald Bisaso (in 2006) and Mr. Mark Byaruhanga (2006 - 2008). The views of this article do not necessarily reflect the position of Makerere University. Any errors in this paper remain the responsibility of the authors.

\section{Statement of Competing Interest}

The authors have not competing interest.

\section{References}

[1] Armstrong, M., A handbook of human resource management practice, $\left(10^{\text {th }}\right.$ ed.), Kogan Page, London 2006.

[2] Brent, R. R., Recognizing that everyone in the institution is a teacher. Pursuing excellence in higher education. Eight fundamental challenges Jossey-Bass San Francisco, 2004.

[3] Briggs, S., "Changing roles and competencies of academics" in Active Learning in Higher Education The Higher Education Academy and SAGE Publications (London, Thousand Oaks, CA and New Delhi) Vol. 6(3): 256-268, 2005.

[4] Briggs, S. \& Tang, C., Teaching for Quality Learning at University $4^{\text {th }}$ Edition; Society for Research into Higher Education, 2014.

[5] Bryman, A., Social Research Methods, Oxford: Oxford University Press, 2001.

[6] Cahn, S. M., Scholars who teach. The art of college teaching. Chicago: Nelson- Hall, 1978.

[7] Cowan, J., On becoming an innovative teacher: reflection in action. Milton Keynes: Open University Press, 1998.

[8] Davis, M., Barriers to reflective practice: The changing nature of higher education Active Learning in Higher Education 4(243) SAGE 6(3), 256-268, 2003.

[9] Delvin-Scherer, R. \& Sardone, N. B., "Collaboration as a Form of Professional Development: Improving Learning for Faculty and Students”. College Teaching Vol. 61 (Issue 1), 2013, pages 30 37. 
[10] Du Plessis, J. \& Muzaffar. I., Professional Learning Communities in the Teachers' College A Resource for Teacher Educators USAID Educational Quality Improvement Program 1 (EQUIP1), 2010.

[11] Driel Van J. H. \& Berry A.,"Teacher Professional Development Focusing on Pedagogical Content Knowledge" Educational Researcher, 2012, Available at http://edr.sagepub.com/content/41/1/26 Retrieved on 21/10/2014.

[12] Eraut, M., Developing Professional Knowledge and Competence. London: Falmer Press, 1994.

[13] Freire, P., Pedagogy of the oppressed. NY: Herder \& Herder, 1975.

[14] Haycock, K., "Good Teaching matters a lot: How well qualified teachers can close the gap”, Thinking K16 Vol. 3 (Issue 2), 1998 The Education Trust.

[15] Healey, M., "Developing the scholarship of teaching in higher education: a discipline-based approach", Higher Education Research and Development, Vol. 19, No. 2, pp. 169-189, July 1, 2000.

[16] Hoekstra, A. and Korthagen, F., "Teacher learning in a context of educational change: Informal learning versus systematically supported learning” Journal of Teacher Education, 61(76), 2011.

[17] Hughes, P., "Teachers on Society, Teachers Professional Development”, Journal of Learning Disabilities 37 (3) 248-55, 1991.

[18] Kasozi, A.B. K., African universities' capacity to participate in global higher education supply and production, 2003, Unpublished Manuscript.

[19] Kasozi, A.B. K., Musisi, N., Katunguka, S. \& Asimwe, D., Decentralization and tertiary institutions of learning in Uganda, Report to the Rockefeller Foundation, 2002.

[20] Kennedy, A., "Models of Continuing Professional Development: a framework for analysis”, Journal of In-service Education, Volume 31, Number 2, 2005.

[21] Knowles, M., The Modern Practice of Adult Education: From Pedagogy to Andragogy, $2^{\text {nd }}$ ed. Chicago: Follett 1980.

[22] Koring, B., Das Theorie-Praxis-Verhältnis in Erziehungswissenschaft und Bildungstheorie. In: J. Petersen \& G. O. Reinert Bildung und Erziehung Donauwörth: Auer, 1997.

[23] Makerere University, ICT Policy/Master Plan (2010 - 2014), Makerere University printer, Kampala (2010).

[24] Makerere University, Report of the Teaching and Learning Subcommittee of Senate, Makerere University printer, Kampala, 2010.

[25] Makerere University, Quality assurance policy framework, Makerere University printer, Kampala (2007).

[26] Makerere University, Strategic Plan 2008/09 -2018/19 Makerere University printer, Kampala.

[27] Makerere University Planning and Development, Unit cost per faculty at Makerere University: A study to analyze the consequences of expansion in terms of cost of developing and maintaining academic standards. Makerere University printer, Kampala, 2003.

[28] Makerere University, Report of the Quality Assurance Task Force, Makerere University printer, Kampala, 2006.

[29] Mamdani, M., Scholars in the marketplace. Dilemmas of neoliberal reform at Makerere (1989 -2005). Kampala: Fountain Publishers, 2007.

[30] McCrickerd, J., "Understanding and Reducing Faculty Reluctance to Improve Teaching," College Teaching, Vol. 60, Issue 2, pages 6-64, 2012.
[31] Merriam, S.B, Qualitative research and case study applications in education, San Francisco, CA: Jossey-Bass, 1998.

[32] Middleton, S., Educating feminist: Life history study, In S. Acker, (Ed). Teachers, Gender and Career, New York: Falmer Press, 1989.

[33] Mohamedbhai, G., "Massification in higher education institutions in Africa: Causes, consequences, and responses," in International Journal of African Higher Education, Vol. 1, No. 1, p. 59-83, 2014.

[34] Monk, M., In Service for Teacher Development in Sub-Saharan Africa - A Review of Literature Published between 1983-1997 Education Research Paper No. 30, 64 p. Department for International Development, 1997.

[35] Namubiru, S. P., "Opportunities and threats to learning: lessons from a pedagogical workshop for faculty at a higher education institution,” in Journal of Education and Training Studies, Vol. 2, No. 1.

[36] Namubiru, S. P., The Theory-Practice Discourse in Initial Teacher Education: Perspectives, Problems and Opportunities, a published $\mathrm{PhD}$ Thesis of Bayreuth University, Bayreuth African Studies, Germany, 2006

[37] New Vision Daily Newspaper, Do the best students always make good lecturers. The Education Vision, February $23^{\text {rd }} 2008$.

[38] Pew, S., Andragogy and pedagogy as foundation theory for student motivation in higher education, Student Motivation 19 (3) 250-273, 2007

[39] Reynolds. J., Caley, L., \& Mason, R. How do people learn? London: CIPD. 2002

[40] Rhodes, C. \& Beneicke, S., Professional Development Support for Poorly Performing Teachers: challenges and opportunities for school managers in addressing teacher learning needs, Journal of In-service Education, 29, pp. 123-140, 2003.

[41] Rogers, C.R. Freedom to learn. Columbus, Ohio: Merrill, 1983.

[42] Schön, D.A., The reflective practitioner: How professionals think in action. London: Temple Smith, 1983.

[43] Seidman, I., Interviewing as qualitative research: A guide for researchers in education and the social sciences. New York: Teachers College Press, 1998

[44] Shulman, L.S., Knowledge and teaching: Foundation of the new reform. Harvard Education review 57. 1-22, 1987.

[45] Sparks, D., How to use this e-news letter, Transforming Professional learning 1, 1-2

[46] Strike, A. K., Is Teaching a Profession: How Would We Know? In: R. L. Schwab (Ed.): Research-Based Teacher Evaluation: A Special Issue of the Journal of Personnel Evaluation in Education. Vol. 4, No. 1, Bolton: Kluver Academic Publishers, 91-117, 1990

[47] Tizard, J., Minty, I., \& Derek, N., Meeting the staff development challenges presented by creating a University. Active Learning in Higher Education, 2(164) SAGE Publications, London, Thousand Oaks, 2001.

[48] The University of East Africa Development Plan, (1967/70).

[49] Truscott, D., Swars, S., Smith, S., Thornton-Reid, F., Zhao, Y., Dooley, C., Williams, B., Hart, L., \& Mathews, M., A crossdisciplinary examination of the prevalence of mixed methods in educational research: 1995-2005. International Journal of Social Research Methodology, 13(4): 317-328, 2009, Retrieved 4 November, 2013 from http://www.informaworld.com/smpp/section?content=a913708351 \&fulltext $=713240928$.

[50] Vavrus, F. Thomas, M., and Bartlett, L., Ensuring quality by attending to inquiry: Learner-centered pedagogy in sub-Saharan Africa Fundamentals of Teacher Education Development for UNESCO-IICBA, 2011. 